DOI: https://doi.org/10.15688/nav.jvolsu.2020.1.1

UDC 930.26(470+571):903.25

Submitted: 24.02 .2020

LBC 63.48(2)-417

Accepted: 29.04 .2020

\title{
JEWELLERY FROM BURIAL 2 KURGAN 1 FILIPPOVKA 1 CEMETERY: MANUFACTURING TECHNIQUES, PURPOSE AND SEMANTICS OF IMAGES
}

\author{
Olga V. Anikeeva \\ State Research Institute for Restoration, Moscow, Russian Federation
}

\section{Galina Yu. Kolganova}

Institute of Oriental Studies of the Russian Academy of Sciences, Moscow, Russian Federation; State Museum of Fine Arts named after A.S. Pushkin, Moscow, Russian Federation

\begin{abstract}
The article is dedicated to the publication of the unique jewelry which was found in the untouched noble female's grave-pit of the Early Sarmatian elite burial ground located at Southern Urals. It stands out with an unordinary complicated construction, polychrome style, a variety of materials and techniques used in its manufacture, central disc containing cloisonne artwork. Analysis of the item's burial context convincingly showed this item was not worn as a decoration in social life, but it was the precious relic used in religious ceremonies and ritual practices for short periods of time. A detailed study of manufacturing technology allows us to reconstruct the fastening ways and application methods for this jewelry. The search of analogies for images placed on the central medallion, made it possible to clarify its compositional semantics. Its central character is the sacred tree, guarded by the divine power of "khvarenah" deity. "Khvarenah" is presented by two guises - the winged sun disc and the sacred Veraghna birds. General meaning of the ritual reflects the idea of increasing fertility: ensuring the well-being and increasing offspring numbers, health, wealth and prosperity of the family. New Assyrian compositional scheme used in the medallion. It appeared at the beginning of the IX century BC and actively spread in Urartu and pre-Achaemenid Media since the VIII-VII centuries BC. This relic was found in the early nomadic burial site dating back to the IV century BC. All these show the significant continuity of ancient Iranian religious cults. They continue to exist in the satrapies of Achaemenid Iran, they are perceived by the elite of the Sarmatian tribes of the Southern Urals and they spread in a nomadic environment.

Key words: South Urals, early nomads, Filippovka 1 kurgan 1, disk-shaped jewelry, construction, fastening method, imagery composition, medallion plot.

Citation. Anikeeva O.V., Kolganova G.Yu., 2020. Jewellery from Burial 2 Kurgan 1 Filippovka 1 Cemetery: Manufacturing Techniques, Purpose and Semantics of Images. The Lower Volga Archaeological Bufletin: vol 19 no $11_{12 p}$ 6-275 (in Russian). DOI: https://doi.org/10.15688/nav.jvolsu.2020.1.1

\section{ЮВЕЛИРНОЕ ИЗДЕЛИЕ ИЗ ПОГРЕБЕНИЯ 2 КУРГАНА 1 МОГИЛЬНИКА ФИЛИППОВКА 1: ТЕХНИКА ИЗГОТОВЛЕНИЯ, НАЗНАЧЕНИЕ И СЕМАНТИКА ОБРАЗОВ}

\section{Ольга Викторовна Аникеева}

Государственный научно-исследовательский институт реставрации, г. Москва, Российская Федерация 


\section{Галина Юрьевна Колганова}

Институт востоковедения РАН, г. Москва, Российская Федерация; Государственный музей изобразительных искусств им. А.С. Пушкина, г. Москва, Российская Федерация

Аннотация. Статья посвящена публикации уникального ювелирного изделия, найденного в не тронутом грабителями захоронении знатной женщины раннесарматского элитного могильника на Южном Урале. Его отличают неординарная сложная конструкция, полихромный стиль, разнообразие материалов и технических приемов изготовления, наличие композиции на центральном диске украшения, выполненной в технике перегородчатой инкрустации (cloisonné work). Анализ контекста предмета в погребении и выявленных особенностей его технологии изготовления и конструкции убедительно показал, что предмет не носился как украшение в повседневной / светской жизни, а служил драгоценной реликвией, которая могла использоваться только кратковременно в религиозных церемониях и ритуальных практиках. Детальное исследование технологии изготовления позволяет реконструировать способы крепления и использования предмета. Поиски аналогий образам, представленным на центральном медальоне, позволили уточнить их семантику и предложить смысловую нагрузку составленной композиции. Ее центральным персонажем является священное дерево, охраняемое божественной силой «khvarenah», представленной в двух ипостасях - крылатого солнечного диска и священных птиц Veraghna. Общий смысл ритуалов отражает идею приумножения плодородия во всех его проявлениях: обеспечении благополучия и приумножения потомства, здоровья, богатства и преуспевания рода. В медальоне применяется новоассирийская композиционная схема, которая появляется в начале IX в. до н.э. и широко распространяется в VIII-VII вв. до н.э. на территориях Урарту и доахеменидской Мидии. Находка реликвии в раннекочевническом погребении IV в. до н.э. свидетельствует о широкой преемственности древнеиранских религиозных культов, которые продолжают существовать в сатрапиях ахеменидского Ирана, воспринимаются элитой сарматских племен Южного Приуралья и распространяются в кочевнической среде.

Ключевые слова: ранние кочевники Южного Приуралья, могильник Филипповка 1, дисковидное изделие, конструкция, способ крепления, композиция, сюжет медальона.

Цитирование. Аникеева О. В., Колганова Г. Ю., 2020. Ювелирное изделие из погребения 2 кургана 1 могильника Филипповка 1: техника изготовления, назначение и семантика образов // Нижневолжский археологический вестник. Т. 19, № 1. С. 6-27. DOI: https://doi.org/10.15688/nav.jvolsu.2020.1.1

Введение и археологический контекст находок. При доследовании в 2013 г. царского кургана 1 могильника Филипповка 1 Приуральской археологической экспедицией ИА РАН под руководством Л.Т. Яблонского было обнаружено не тронутое грабителями захоронение женщины, которая умерла в возрасте 35-40 лет [Яблонский, 2014, с. 6]. Оно располагалось под восточной полой кургана вблизи края насыпи, имело прямоугольную в плане форму и общие размеры 3,6 × 2,6 м. Длинной осью могила была ориентирована в направлении края насыпи кургана в данном секторе. Глубина ямы составляла 3,7 м. На уровне погребенной почвы, вдоль южной стенки и в заполнении южного сектора могильной ямы были зафиксированы крупные остатки бревен деревянного перекрытия погребальной камеры. Погребенная лежала на спине, головой на юг, в вытянутом положении (рис. 1). По совокупности необычайно богатого и типологически разного сопровождающего инвентаря захороненная женщина обладала высо- ким социальным статусом [Яблонский, 2014, с. 5-6; 2016б, с. 15].

Среди разнообразных украшений выделяется группа ювелирных изделий, основной функцией которых являлось их использование в религиозных церемониях и ритуальных практиках, а не в бытовой / светской жизни: дисковидное изделие (рис.1,1) с разнообразными подвесками [Яблонский, 2016а, с. 748-749; Yablonsky, Treister, 2019, p. 92-93], серебряное зеркало (рис. 1,2) с трехчастной мифологической композицией, наборы для нанесения татуировок (рис.1,4), фрагменты кожаного пояса (рис.1,5) с разнообразными подвесками [Яблонский, 2014, с. 5; 2015, с. 98, 100; 2016б, с. 1516], амулет-подвеска (рис. 1,3) и бусина-пронизь (рис. 1,6) [Яблонский, 2016а, с. 747; Аникеева, Яблонский, 2018, с. 65-67], каменные печати (рис. 1,7).

Дисковидное изделие (рис. 1,1), которому посвящена эта работа, находилось в пределах большого короба в изголовье слева от погребенной, так как сверху оно было пере- 
крыто фрагментами органики, аналогичными по строению лубу нижней части короба, и лежало в характерном заполнении плотных комков коричневатого суглинка, как и другие многочисленные предметы из этого короба. Изделие лежало лицевой стороной диска вниз, все подвески на цепочках, обрамляющие края центрального диска, были аккуратно уложены на оборотную сторону диска [Яблонский, 2016a, с. 748-749; Аникеева и др., 2018, с. 212 213; Yablonsky, Treister, 2019, p. 81].

Для определения функционального назначения предмета нужно провести детальное изучение технологии изготовления, конструкции и порядка сборки отдельных элементов ${ }^{1}$, что позволит предложить вероятные способы его крепления и использования в ритуальных практиках.

Анализ иконографии образов, представленных на центральном медальоне, важен для определения семантики образов, смыслового значения его композиции и интерпретации осуществляемых при участии данного изделия культовых действий.

Наблюдения и измерения проводились на оптическом бинокуляре МБС-10 при увеличениях 16-56Х. Для замеров перегородок центральной части медальона использовался специально изготовленный щуп с зажимом. Фотофиксация и макросъемка выполнены цифровыми камерами Canon G11 и Nikon, микросъемка - цифровой камерой Nikon D50, установленной на оптический микроскоп МБС-10.

Изучение технологии изготовления. Центральная часть изделия представлена диском, который обрамлен радиально прикрепленными к нему простыми и сложными подвесками (рис. 2, 3). Основа, на которой укреплены элементы диска, представляет собой тонкую круглую пластину. При измерении толщины листового металла края пластины в местах, где отсутствовали заусенцы при обрезке и монтажный припой, она оказывалась близкой к 0,3 мм. Все открытые поверхности листового металла имеют гладкую неполированную поверхность, из чего следует, что листовые заготовки после ковки были отшлифованы. Поверхность пластины по краю была обрезана ножом в виде фестонов. С лицевой стороны на пластину диска золотым припоем напаяны различные декоративные элементы, описание которых дано от периферии к центру.

Ряд пирамидок из шариков зерни, по 4 шарика каждая (рис. 2,1). С лицевой стороны декорируют фестончатый край пластинчатой основы. Они напаяны на основу без излишка припоя, хотя его мениск хорошо виден. Диаметр шариков зерни колеблется в пределах от 1,9 до 2,5 мм. Спаянные элементы пирамидок часто оторваны друг от друга или имеют трещину по припою. Образование трещин могло произойти при деформации предмета и говорит о хрупкости припоя. В некоторых местах припой связывает не касающиеся друг друга шарики соседних пирамидок или заполняет разрыв между шариком и лежащим рядом кольцом для цепочек [Аникеева, Яблонский, 2019б, с. 26].

После напаивания зерни край пластины был подрезан по контуру зерни зубцами. Подрезка выполнялась ножом или подобным ему инструментом, край реза получил загиб и заусенцы во многих местах, направленные вверх, в сторону зерни. Кроме этого, пластина основания загнута вверх на вершинах краевых зубцов, у внешних шариков зерни, на высоту до половины их диаметра. Эти загибы плотно охватили каждый шарик и оказались к ним припаянными. Это возможно либо, если край был загнут до укладки зерни по всему, тогда еще ровному, краю пластины. Потом разложена и пропаяна зернь, обрезан край. Либо загиб образовался при обрезке края после пайки, а припой затек между шариками и загнутым краем в процессе последующих паек диска (например, припаивания деталей оборотной стороны). Второй вариант кажется более вероятным.

Замкнутое кольц̧о (рис. 2,2) из гладкой, круглой в сечении «проволоки», на которой видны идущие по спирали линии стыка, образовавшиеся при ее изготовлении скатыванием из ленты. Диаметр колеблется в пределах 1,55-1,8 мм. Концы срезаны или запилены под углом и сведены так, что один конец накрывает другой. Подгонка не точная, припоя недостаточно для заполнения шва.

Два кольияа из шнура (рис. 2,3), свитого из двух гладких проволок: наружное кольцо свито против часовой стрелки, внутреннее по часовой стрелке. Вместе они образуют по- 
лоску елочного орнамента. «Проволока» шнуров скручена из ленты металла и спаяна между собой. Диаметр проволоки около 0,9 мм. Общий диаметр каждого шнура 1,75 мм.

Кольцо из полосы для крепления центральной части диска - медальона с инкрустацией (синоним кольцо-каст). Концы полосы спаяны внахлест с последующим утоньшением места пайки проковкой или опиловкой, кольцо-каст припаяно к диску. Получившийся бортик имеет среднюю высоту 2,4 мм [Аникеева, Яблонский, 2019б, с. 28].

Примененный способ крепления медальона принципиально отличается от наиболее распространенной разновидности глухого каста, когда к закрепляемой вставке прижимается или вся стенка каста, или ее верхняя часть, а торец каста становится наклонным и утоньшается. В нашем случае верхний торец кольца-каста обработан скользящим вдоль кольца движением давящим инструментом с образованием заусенца, направленного к медальону с инкрустацией и нависающего над его краем. На торце видны следы инструмента, которым проводилось крепление. Видимая толщина обработанного торца кольцакаста, перпендикулярного его стенке, достигает 0,55 мм. В нескольких местах из-за деформации медальона бортик отошел от него и видна внешняя стенка медальона. При креплении медальона и его инкрустации, а также вставок в подвесках-кастах (см. ниже) край металла перегородок и кастов «навален» на вставку и немного возвышается над ней. Эта разновидность закрепки известна с древнейших времен, например инкрустированные перстни из Эгины [Higgins, 1979]. Позднее в ювелирной технике применяется сходный прием для крепления плоских камней, так называемая зеркальная оправа (чтобы верх камня и его оправа оказались в одной плоскости). В этом случае ребро каменной вставки должно быть «завалено» или иметь небольшую фаску.

В центре диска помещен медальон $c$ инкрустацией диаметром 4,5 см (рис. 2, 4). Он изготовлен отдельно и вставлен в кольцокаст основного диска после окончания работ, связанных с пайкой всех элементов диска изделия (в том числе и деталей крепления оборотной стороны). Медальон удерживается заусенцем на торце основного каста, как описано выше. Утраты инкрустации медальона позволили провести измерения, уточняющие его конструкцию. Замер высоты кольца-каста с наружной стороны и расстояния от верха этого кольца до дна медальона показал, что медальон имеет собственное дно, к которому припаяны перегородки. Они изготовлены из полосок металла и включают: три концентрических кольца (внешнее кольцо является границей вставного медальона, дно которого нигде не выступает за это кольцо); горизонтальную нижнюю границу полукольца крылатого диска; разной длины прямые и изогнутые перегородки, образующие орнамент внутри колец и изображения крылатого диска в верхней части и дерева - в основной зоне медальона; овал основания и корней дерева.

Места стыков замкнутых перегородок не определяются из-за их точной подгонки и пайки. Верхние торцы перегородок после припаивания сошлифованы в одну плоскость и так же, как на кольце крепления медальона, имеют многочисленные следы обработки давлением для обеспечения дополнительного крепления инкрустации. Из-за этой обработки торцов перегородок их толщина кажется разной даже в пределах одного элемента. Таким образом, элементы инкрустации удерживаются не только на мастике, но иногда и за счет специально образованных заусенцев на перегородках.

Рисунок полихромного медальона (рис. 4) выполнен в технике перегородчатой инкрустации (клуазонне). Для вставок использовалось синее и красно-оранжевое прозрачное и бирюзовое непрозрачное стекло. Ячейки инкрустации между внешним бортом диска и первым кольцом четырехугольные, шаг их орнамента определяется цветом вставок: синяя бирюзовая - красная - бирюзовая. Форма ячеек между первым и вторым кольцом треугольная. Вставки в них по цвету стекла образуют два кольца: внешнее - с чередующимися синими и красными треугольниками, внутреннее - из бирюзовых треугольников.

Центральная композиция диаметром 2 см представлена двумя ярусами, разделенными горизонтальной перегородкой. В верхнем ярусе на бирюзовом трапециевидном основании помещено изображение крылатого 
солнечного диска. Каждое крыло состоит из двух ячеек: верхней - со вставкой красного цвета и нижней - с бирюзовой вставкой. Диск изображен в форме сдвоенных окружностей, диаметр которых уменьшается к центру. В центре нижнего яруса расположено дерево с удлиненным в форме неправильного ромба стволом голубого цвета, окаймленным по периметру семью однотипными округлыми стилизованными листьями / ветвями бирюзового и красного цвета, последовательно чередующимися. Шесть расположены симметрично вдоль ствола, по три с каждой стороны, и один венчает вершину. Внизу ствол обрамляют два красных симметричных серповидных полукруга с опущенным вниз узким краем и широким основанием, поставленным на овальное основание голубого цвета. По бокам дерева помещены фигуры двух птиц, выполненные из плоских золотых пластин. На участке утраты стекла инкрустации просматривается вертикальная стенка. Следовательно, пластины опираются на скрытые под ними вертикальные стенки, а наружная поверхность пластин лежит в одной плоскости с верхними краями перегородок инкрустации. Толщина пластин близка толщине перегородок. Профильные изображения птиц симметричны: голова, крыло и хвост каждой птицы развернуты к краям диска, туловище изогнуто вдоль дерева, лапы опираются на серповидные полукружия. Головы птиц остроклювые, крылья имеют фестончатые края, загнутые вверх. Обрезанный по прямой линии конец хвоста наклонен вниз. На шее гравировкой выделены фрагменты оперения, на голове - округлые глаза. Гравировка нанесена инструментом с кольцевым отпечатком, причем при нанесении линий на шее инструмент ставился под углом для нанесения полуколец.

Ко дну основного диска припаяно 27 незамкнутых проволочных петель (рис. 3,2), с лицевой стороны места их припоя декорированы пирамидками зерни (рис. 2,1). К 20 петлям крепятся два типа подвесок: простые (в форме глухого серповидного каста) и сложные, состоящие из цепочек и трех видов привесок, прикрепленных к звеньям цепочек. На верхних (относительно композиции медальона) 7 петлях присутствуют только подвески / цепочки (рис. 2, 3), подвешенные отлично от остальных - оборотной стороной.

Простые серповидные подвески (рис. 2,4) в форме полумесяца представлены глухим кастом с дном. В касты на мастике закреплены вставки из фритты ${ }^{2}$ красного и голубого цветов. Каст напаян на подложку такой же, как у него, формы, но большую по размеру, так что образована ступенька, на которую по периметру напаян сплошной ряд зерни. Диаметр зерни у кастов подвесок 0,6-0,8 мм. Обрезка края подложки, сделанной сначала с запасом, проведена после пайки зерни. Абсолютно идентичным по технологии приемом выполнено оформление зернью фестончатого края диска медальона. К оборотным сторонам подвесок припаяно по проволочной петле. Петли расположены в плоскости подложки кастов и выступают из-за них сверху так, что могут свободно двигаться по петлям диска. Острые концы подвесок направлены вниз. Серповидные подвески надеты на петли диска первыми, поэтому они оказываются на лицевой стороне навершия. По технике изготовления аналогичны подвескам в форме квадратного ромба в этом изделии, а также квадратным кастам, которые присутствуют в оформлении других ювелирных украшений этого погребения [Аникеева и др., 2018, рис. 1, 2; Аникеева, Яблонский, 2019а, с. 19, pис. 2,11,12; Yablonsky, Treister, 2019, p. 88, fig. 8,1,2]

Сложные подвески сделаны из цепочек, каждая из которых осложнена тремя различными привесками (рис. 3,3). Тип цепочек называется «звено в звено», использован его простейший вариант - одинарная (однорядная) цепь. Звенья такой цепи собираются последовательно в один ряд. Важна технология сборки. При изготовлении такой цепи сначала готовятся отдельные паяные звенья в виде колец, потом каждое изгибается в двух направлениях: первый изгиб дает сильно вытянутый овал, после второго образуется звено с двумя петлями (по одной сдвоенной с каждой стороны). Затем звенья собирают, продевая каждое новое в сдвоенную петлю предыдущего. Первое звено, с которого начинается сборка, можно сначала продеть в замкнутое кольцо какого-либо элемента украшения, после присоединения второго звена это уже не- 
возможно. Петли последнего звена собранной цепи необходимо надеть на какое-либо разомкнутое кольцо и свести его, иначе звено отделится. В нашем случае первые звенья каждой цепочки вставлены в петли, припаянные к четырехлопастным подвескам, а последние вложены в разомкнутые петли крепления оборотной стороны диска.

Важное следствие этого типа сборки: если составления цепочки начато с надевания на замкнутый элемент (петли четырехлопастных концевых подвесок - рис. 3,4), то снять любое звено, кроме последнего, без его разрезания или разделить цепь по длине на части можно только разбирая ее по одному звену, начиная с противоположного конца. Цепочки надеты на петли диска после серповидных подвесок (там, где они есть) и оказываются за ними.

Длина цепочек меняется $(1,5-4$ см), что обусловлено различным количеством звеньев (рис. 2, 3) ${ }^{3}$. К верхней кромке диска (если ориентироваться на изображение в центре) прикреплены 7 коротких цепочек: шесть из них имеют 5 звеньев, одна - 3 звена (рис. 2,5). Нижний край окаймляют 10 коротких цепочек в 6 звеньев. Между ними расположены 10 боковых цепочек (по 5 с каждой стороны), длина которых уменьшается сверху вниз. Боковые цепочки в центре (по 3 с каждой стороны) симметричны, и количество петель в них последовательно уменьшается на одно звено сверху вниз (11, 10 и 9 звеньев). В верхних и нижних цепочках количество звеньев отличается на одно звено, но в сумме имеет одинаковое значение - 20 звеньев: с правой стороны они имеют 13 и 7 звеньев, с левой -12 и 8 звеньев. Число боковых (10 шт.) и нижних (10 шт.) цепочек с подвесками - одинаково и составляет в сумме 20. Они ориентированы к диску лицевой стороной привесок, и поверх них привешены 20 серповидных подвесок, которые отсутствуют на 7 верхних цепочках [Аникеева, Яблонский, 2019б, с. 29].

В верхней трети цепочек расположены привески в форме квадратного ромба (рис. 2,6$)$ с глухим кастом $(0,5 \times 0,5$ см), в котором находились вставки из рудных минералов (большинство их разрушено; определение рудного минерала в сохранившихся фрагментах показало, что они были сделаны из пири- та). Способ их изготовления идентичен технике простых серповидных подвесок. Касты окаймлены по внешнему бортику рядом зерни и имеют пирамидку из трех шариков зерни в нижнем углу ромба. Средний диаметр зерни $-0,6-0,8$ мм. К обороту кастов в верхних углах припаяны проволочные петли для крепления к цепочкам.

Техника их исполнения близка открытым кастам с аналогичными вставками на звеньях расшивки рукавов платья, каменные вставки в которых сохранились значительно лучше [Аникеева, Яблонский, 2019а, с. 19, рис. 2,11,12]. Минералого-петрографическое определение материала вставок из ромбических кастов звеньев расшивки показало, что среди них преобладают рудные минералы олова (касситерит), цинка (сфалерит), в нескольких кастах присутствуют вставки из пирита.

Привески из проволочных стерженьков (рис. 3,5). Каждая сделана из отрезка проволоки, к расплющенному концу которой припаяна пирамидка из четырех шариков зерни диаметром 1,6-2,5 мм. При сборке на проволоку до упора в пирамидку надевалась бусина (цилиндрическая или округлая из глухого стекла голубого и белого цвета, сохранилось 3 шт.), затем проволока пропускалась в сдвоенное звено цепочки, сгибалась в петлю и обвивалась вокруг собственной оси в виде спирали, фиксируя бусину и притягивая элемент к цепочке. Первоначально эти и ромбические привески располагались под прямым углом к цепочке. Идентичными подвесками украшены цепочки на височных кольцах из этого погребения [Аникеева и др., 2018, рис. 3, 4; Yablonsky, Treister, 2019, p. 88, fig. 8,1,2].

Все цепочки заканчиваются четырехлопастными удлиненными привесками длиной 2,5 см (рис. 3,6). Каждая состоит из двух согнутых под прямым углом тонких овальных пластинок, спаянных между собой по ребрам сгиба. Снизу припаяны пирамидки из пяти шариков зерни. В трех ребрах сгиба размещены ряды шариков зерни, в четвертом (во всех случаях со швом пайки) - зернь отсутствует. Очевидно, ребро без зерни фиксирует оборотную сторону привески, что отчетливо видно на 7 верхних коротких цепочках, подвешенных оборотной стороной (рис. 2,7). Размер зерни в основном - 1,1-1,2 мм. К верх- 
ним концам, в углубления между верхними шариками зерни и стенкой пластин, припаяны «проволочные» петли для крепления.

Эти привески и привески в форме стерженьков с бусинами были широко распространены в кочевнической среде, поскольку встречаются как в украшениях других погребений могильника Филипповка 1, так и в ювелирных изделиях из одновременных могильников Южного Урала [Трейстер, Яблонский, 2012, с. 376, 390].

Ближайшей и пока единственной аналогией предмету по конструкции и технике изготовления (медальон в технике перегородчатой инкрустации, вставленный в диск, обрамленный радиально расходящимися цепочками с подвесками) является находка ювелирного изделия из погребения 1 кургана 17 могильника Филипповка 1 [Трейстер, Яблонский, 2012, с. 145]. Объединяет их одинаковая конструкция: центральный диск, идентично декорированный, вставленный в него медальон с изображением в технике «клуазоне», наличие идентичных цепочек-подвесок разной длины и подвесок на них (концевые четырехлопастные, подвески из проволочек с бусинами), устройство крепления (см. ниже). Однако символика инкрустации на диске иная и представлена восьмилучевой звездой с кругом в центре.

Отметим, что большинство аналогий композиционным элементам медальона с перегородчатой инкрустацией (фризы из треугольников, пальметты, крылатый диск) происходят преимущественно из находок с территории Кавказа и Передней Азии [Рябкова, 2014 , с. 165 , рис. $1,7,8,10$; Yablonsky, Treister, 2019, p. 125-126]. Изображения шестилучевых звезд с окружностью в центре, выполненные в технике перегородчатой инкрустации, распространены в уздечных бляхах из памятников Закавказья, датированных VIII-VII вв. до н.э. [Рябкова, 2014, с. 165, рис. 1,1-5]. Вопрос об истоках техники cloisonné work неоднозначен: в Месопотамии и Иране такие изделия появляются во второй половине II тыс. до н.э., и их появление, вероятно, было обусловлено египетским влиянием, где эта техника широко используется в украшениях начиная с III тыс. до н.э. [Maxwell-Hislop, 1974, p. 167-168]. Э. Порада предполагает, что находки в Хасанлу и Зивийе, датируемые IX-VII вв. до н.э., не дают достаточно оснований для утверждения об иранском происхождении этой техники, и возможно, что она возникла к северу от Ирана [Porada, 1965, p. 118]. Т.В. Рябкова, анализируя происхождение и распространение изделий с перегородчатой инкрустацией в предскифских и раннескифских памятниках, приходит к выводу, что украшения с перегородчатой инкрустацией получают широкое распространение в элитных курганах Нагорного Карабаха начиная с XII в. до н.э., что может свидетельствовать о зарождении этой техники в Закавказье [Рябкова, 2014, с. 167].

Другой, не столь однозначной, аналогией является подвеска, происходящая также из могильника Филипповка 1. Ее контекст не определен. Она найдена в 150 м к северо-северо-востоку от кургана 1 [Яблонский, 2013, с. 220, кат. 3113]. М.Ю. Трейстер относит ее к височным подвескам [Трейстер, Яблонский, 2012 , Т. I, с. 144,393 , рис. 74 , с. $531-532$, табл. 97-98]. Конструкция ее нижней части аналогична основанию представленного изделия: овальный лист, с оборотной стороны которого, вдоль края листа, припаяны идентичные по строению незамкнутые петли для однорядных цепочек, осложненных боковыми привесками (среди которых есть четырехлопастные и подвески из проволочных стерженьков) и заканчивающихся овальными привесками с двусторонними изображениями морд хищных зверей. Есть ли крепление в центре оборотной стороны овала - не видно. С лицевой стороны овала укреплена литая фигурка стоящего кабана $(4,0 \times 2,5 \times 1,2$ см), на спине которого припаяно небольшое кольцо для подвешивания $(\mathrm{d}=1,1-1,2 \mathrm{~cm})$.

В ранних статьях при анализе конструкции изделия предполагалось, что оно было собрано по принципу последовательной сборки [Аникеева и др., 2018, с. 212, 214] с использованием уже готовых элементов разнообразного декора. Исследование технических приемов изготовления позволило выделить детали, важные для установления способов его использования. Основной «трудозатратной» операцией являлось изготовление основы (пластина с диском), крепления самого изделия и петель для подвешивания подвесок с последующим декорированием как петель, так и диска с лицевой стороны. Затем в конструк- 
цию вставлялся готовый медальон с инкрустацией и подвешивались разные подвески. Цепочки с привесками собирались снизу вверх один раз, после сборки изменить конструкцию сложно - надо последовательно разомкнуть каждое звено цепочки сверху вниз. Легко можно только добавить или убрать одну петлю сверху. Важно, что менять позицию цепочки вокруг диска довольно просто, так как 27 петель на диске незамкнуты. Трасология поверхности петель и участков пластины под ними показывает, что это неоднократно проводилось.

Таким образом, при использовании изделия проводилось осознанное, а не хаотическое изменение взаиморасположения цепочек разной длины вокруг диска, связанное с функциональным назначением предмета. Это показывает, что положение верхних 7 цепочек, подвешенных оборотной стороной (рис. 2, 3), симметричное расположение боковых цепочек, равных по количеству нижним коротким 10 цепочкам, не случайно, а несло смысловую нагрузку.

Конструкция и способы крепления изделия (рис. 3,1 ). В центре оборотной стороны диска припаяны четыре крепежные скобы из золотой полосы $(1,3 \times 0,3 \mathrm{~cm})$, образующие каре, которые в центральной части профиля имеют отступ в форме арки для крепления. Под двумя скобами, расположенными по вертикали относительно изображения на медальоне, видны царапины и потертости одного направления, которые отсутствуют на двух боковых скобах. Трасология царапин, проведенная М.В. Нацким, показывает, что они были сделаны заостренным предметом типа «швейной» иглы. Тогда пришивание изделия проводилось преимущественно за две дужки, фиксирующие вертикальное расположение медальона.

По мнению М.В. Нацкого ${ }^{4}$, с точки зрения традиционной ювелирной техники единственным рациональным положением предмета являлось его стационарное горизонтальное крепления к верхнему торцу вертикального стержня за четыре скобы оборотной стороны диска. Конструкция крепежных петель допускает пришивание, притягивание ремешками, использование штифтов и т. п., поэтому и сам стержень мог быть из плотной ткани, кожи, дерева, металла. Это оправдывает большой диаметр петель диска, позволяющий элементам свободно раскачиваться. Вертикальное положение он считает неэстетичным, так как при креплении на перпендикулярном диску стержне элементы, оказавшиеся сверху, при откидывании назад становятся не видны. Если перекинуть их вперед, нижние привески цепочек закроют изображение медальона; цепочки в стационарном положении будут тереться об элементы диска (что по трасологии не установлено); привески с кастами и бусинами будут хаотически свешиваться и перепутываться, цепочки не могут стабильно удерживаться на лицевой стороне из-за конструкции петель.

М.Ю. Трейстер также предполагает горизонтальное крепление украшения, так как форма его скоб подразумевает крепление предмета к мягкой основе. Он считает маловероятным, что украшение являлось навершием жезла, так как в этом случае способ его крепления к жесткой основе (камень, дерево, металл) был бы иным (не уточняя, каким). На этом основании он определил предмет как навершие, украшавшее головной убор [Yablonsky, Treister, 2019, p. 123].

Отметим, что М.В. Нацкий и М.Ю. Трейстер однозначно считают: предмет использовался в стабильном (зафиксированным в определенной позиции) положении и служил навершием для украшения вертикального стержня / посоха или головного убора.

Мы считаем, что предмет в повседневной жизни не употреблялся, а использовался кратковременно при отправлении ритуалов, то есть в постоянном движении. Тогда важной функцией предмета являлись разнообразные положения диска в движении, цель которого заключалась во взаимодействии подвижных цепочек / подвесок с персонажами композиции медальона: они могли скрывать и полностью открывать изображение либо частично перекрывать определенный элемент композиции в зависимости от производимых движений. Важно, что в ходе церемонии позиция диска изменялась.

Привески на 7 коротких цепочках сверху, прикрепленных оборотной стороной, «играют», только если они перекинуты на лицевую сторону медальона, при этом они закрывают изображение крылатого солнечного диска в верх- 
нем ярусе медальона, акцентируя внимание на дереве и двух птицах в центре. Изменение бокового угла наклона позволяет длинным боковым цепочкам перекрывать фигуру одной из птиц. Это возможно при наклонно/вертикальном положении диска. Кратковременность использования объясняет отсутствие потертостей, которые появились бы на диске при трении цепочек о диск при постоянном вертикальном положении предмета. Большой диаметр крепежных петель диска позволяет цепочкам свободно перемещаться при движении и согласуется с результатами трасологического анализа поверхностей крепления изделия, показывающими, что пришивание изделия неоднократно проводилось за две дужки, фиксирующие вертикальное расположение медальона.

\section{Семантика образов и композиции} медальона (рис. 4). Медальон состоит из 2 ярусов, разделенных горизонтальной перегородкой. В верхнем ярусе ( $1 / 3$ объема) помещен крылатый солнечный диск. Диск изображен с помощью трех кольцевидных перегородок, диаметр которых уменьшается к центру. В центpe нижнего яруса помещено священное дерево. По бокам в едином поле с деревом даны симметричные изображения двух птиц.

М.Ю. Трейстер, анализируя сюжет композиции, однозначно связывает изображение крылатого диска с символикой верховного ахеменидского бога Ахура Мазды и на этом основании относит композицию к ахеменидским религиозным сюжетам. Упоминая изображение пальметты при описании, он опускает семантику изображения (что объяснимо, так как в ахеменидских сюжетах подобная иконография пальметты / дерева не известна, а ее иные изображения являются вторичными элементами композиции, разделяющими центральные сцены). Проводя параллели сюжету среди вещей ахеменидского круга, он приводит изображение на верхнем фризе из пекторали, найденной предположительно в районе Ардебиль на северо-западе Ирана и датирующейся первой третью IV в. до н.э., где симметричные фигуры птиц изображены по бокам фигуры Ахура Мазды, а крылатый диск отсутствует [Yablonsky, Treister, 2019, p. 125-126].

Л.Т. Яблонский считал, что «в центре украшения изображено мировое древо с ох- раняющими его крону мифологическими птицами симургами, частично покрытыми рыбьей чешуей. Корни дерева уходят в подземный мир. Венчает композицию распростершая крылья главная птица симург - охранительница» [Яблонский, 2014, с. 5].

Образ «мирового (космического) древа» («древа жизни», «древа плодородия») появляется в глиптике северной Месопотамии в III тыс. до н.э. и распространяется в странах Восточного Средиземноморья во II тыс. до н.э. [MichauxColombot, 2008, p. 349, pl. I, 1,2,8,10,17,20, p. 350, pl. II,28, fig. 14, $A-E]$. О семантике и иконографии стилизованного дерева в искусстве Месопотамии написано много (укажем лишь: [Giovino, 2007]). С его помощью пространство членилось на 3 зоны: небо, земля и подземное царство. Смысл ритуалов с «древом жизни» подразумевал получение благополучия, плодородия, потомства, богатства. Троичность «мирового древа» по вертикали подчеркивалась соотнесением с каждой его частью определенного класса животных: с верхней - птицы (часто две симметрично или одна на вершине, нередко это орел); со средней - копытные, реже пчелы; с нижней - рыбы, земноводные (лягушки, жабы), пресмыкающиеся (змеи), иногда медведь. Таким образом, все три яруса дерева (вершина, ствол и корни) и связанные с ними 3 класса животных подчеркивают идею зачатия и плодородия.

Образ священного дерева зафиксирован практически повсеместно в Ассирии и Урарту. Примененная схема - дерево, фланкируемое фигурами (в данном случае хищных птиц), с крылатым солнечным диском в изголовье типично новоассирийская. Ее истоки уходят в начало II тыс. до н.э., что для нас в данный момент не так важно, как то, что такая композиционная схема вошла в моду с первой половины IX в. до н.э. [Пиотровский, 1959, c. 228, 238-240, 248-254; Giovino, 2007, fig. 1, 13-16, 22, 37-38, 56; Batmaz, 2013, p. 71-83, fig. 11-15, 17-19, 25, 26, 28, 38]. Она активно тиражировалась в VIII-VII вв. до н.э. благодаря глиптике и тканям, композиции вышивок на которых сохранили для нас новоассирийские рельефы. Например, изображение священного дерева, фланкированное профильными фигурами стоящих хищных птиц, головами обращенных к дереву, на фрагментах одежд из 
дворца Ашшурнасирпала II в Калахе [Giovino, 2007, fig. 56]. Территория Урарту, видимо, являлась плацдармом для распространения ассирийской изобразительной схемы со стилизованным (священным) деревом. Разработанная ассирийскими мастерами схема активно использовалась в настенных росписях дворцов урартских царей. Замечательным примером мелкой пластики служит найденная на Кармир-Блуре круглая стеатитовая шкатулка. На ее плоской крышке изображено священное дерево, фланкированное фигурами крылатых гениев с птичьими головами. Над деревом помещен крылатый солнечный диск, а по краю шкатулки - орнамент из переплетающихся окружностей с точкой в центре [Пиотровский, 1959, с. 188; Пиотровский, 1970, ил. 98].

Иконография «древа жизни» в Ассирии и Урарту близка, можно выделить два крайних характерных типа. Стилизованное изображение пальмы (ствол, венчающийся классической пальметтой, или ствол с симметричными горизонтальными ветвями, с остроугольными листьями / плодами на концах) [Giovino, 2007 , fig. 4, 43-45] и сложное кружевное сооружение удлиненно-округлой формы (внутри заполненное переплетающимися тонкими ветвями с характерными остроугольными листьями на концах). Часто по периметру присутствует кайма из мелких пальметт, иногда вписанных в круг [Giovino, 2007, fig. 1-4, 14-16]. Между этими типами существует целый ряд промежуточных разновидностей. Иконография дерева на филипповском медальоне совершенно иная, сильно стилизованная (см. выше), что очевидно отражает процесс активного тиражирования образа на поздней стадии. Аналогий ему среди ассирийских или урартских изображений не найдено. Наиболее близкой аналогией является дерево с девятью ветвями на серебряной чаше, происходящей, по данным А. Судавар, из западного Ирана и датированной поздним VII в. до н.э. [Soudavar, 2018 , p. 26, fig. 22]. Очевидно, количество ветвей на дереве было обусловлено символикой проводимого ритуала. Преобладает изображение деревьев с девятью ветвями, деревья с семью ветвями встречаются реже [MichauxColombot, 2008, p. 350, pl. I, 17; Batmaz, 2013, p. 71,73 , 77, fig. $11,17,19,28, a]$.
На филипповском медальоне изображение крылатого солнечного диска связано, безусловно, не с ахеменидской символикой Ахура Мазды, так как диск изображен в форме трех окружностей с уменьшающимися к центру диаметрами. Это символ абстрактного божества Хварна (Хварно, Фарр), обозначаемый «khvarenah (khvarnah)» и являющийся символом божественной силы (обеспечивающей фортуну), «дарующей сияние (славу), божественную благодать великому (правителю, герою) и сопровождающей его, пока он справедлив (беспристрастен)» [Kia, 2016, p. 211]. Его популярность была высока у иранских племен доахеменидского периода на территории Мидии и стран Восточного Средиземноморья. Согласно древнеиранской легенде [Soudavar, 2005, p. 123-125; 2018, p. 28, fig. 29, a, $29, b, 30]$, «khvarenah» рождается и растет в глубине моря / океана в образе жемчужины (символ «двойной круг» идентичен филипповскому изображению), появляется на поверхности в куче цветущего лотоса и восходит на небо как цветок подсолнуха (символ «розетта»). Другой символ «khvarenah» - крылатый диск, в центре которого отчетливое изображение двойного круга, например на фризе восточных ворот Ападаны в Персеполе. По бокам его - крылатые фигуры сфинксов, символизирующие вечность и незыблемость власти этого божества [Soudavar, 2005, p. 122, fig. 12,3]. Несмотря на полную ассимиляцию указанного символа в религиозной символике правящей верхушки Ахеменидов, власть этого божества остается могущественна и популярна в ее сатрапиях, что находит отражение в цветном панно из глазурованных кирпичей в Персеполе [Soudavar, 2005, p. 126, fig. 12.7].

Это объясняется толерантностью религиозной политики, которую проводили персидские цари. Они не только разрешали свободно проводить ритуальные церемонии, посвященные богам других религий, но и оказывали финансовую поддержку при возведении или восстановлении храмов иных религий. Более того, в сатрапиях священные места других религий находились под защитой и покровительством ахеменидских правителей. Геродот и Страбон упоминают традиционные религиозные различия между персидскими и мидийскими жрецами. Они сообщают, что у иран- 
цев не было храмов или святынь и они молились на открытом воздухе или на вершине горы. Этот ритуал отражен в иконографии Ахеменидов, например на рельефе из Даскалиона в Малой Азии, где в сцене жертвоприношения изображены два иранских жреца в характерных головных приборах, прикрывающих рты. Они держат в руках ритуальные стержни, называемые «barsom» [Curtus, Tallis, 2005, p. 152, fig. 57, p. 153]. Персидский царь Дарий I, определивший религиозные представления правящей верхушки Ахеменидов, использует символ, возвеличивая статус Ахура Мазды, вначале компонуя его над фигурой и подчеркивая, что этот бог обладает властью «khvarenah», а затем и вводя его изображение в центр крылатого диска [Curtus, Tallis, 2005, p. 150; Soudavar, 2005, p. 121-123, 131-133].

Интерпретируя символику и назначение птиц, изображенных по бокам сакрального дерева, мы обратились к источникам, где упоминается священная птица. В арийской традиции отчетлива корреляция «мировой горы» и «мирового древа», а Шьена/Саэна-Симург помещался на вершине «мировой горы», что позволяет связать его образ с тем или иным вариантом «мирового древа» в верованиях индийцев и иранцев. Действительно, в «Ригведе» $[\mathrm{I}, 164,20,22]$ упоминаются два орла, обхвативших одно и то же дерево: один из них ест сладкую винную ягоду. На филипповском медальоне обе птицы отвернулись от дерева, контуры их ног и спины параллельны стволу дерева, мощные лапы стоят на корнях дерева, отогнутые в сторону хвосты внизу замыкаются на внешнем бортике медальона, а макушки голов смыкаются с концами крыльев крылатого диска. Таким образом, ствол и листья дерева вписаны в замкнутое пространство, сверху закрытое размахом крыльев солнечного диска, с боков ограниченное замкнутыми контурами птичьих фигур. Не исключено, что они несут смысловую нагрузку, связанную с изображением крылатого диска, но совершенно отчетливо проявляется их основная функция - охранительная.

В иконографии птиц надо отметить определенную форму крыльев с загнутыми вверх концами, мощные когтистые лапы и характерную форму обрубленного по горизонтали хвоста. На квадратной табличке из зала
32 колонн в Персеполе изображена птица семейства соколиных с идентичной иконографией [Soudavar, 2005, p. 127, fig. 12,8], но в другом контексте: с распростертыми крыльями и расставленными лапами с тройственным изображением сферы «khvarenah»-две в расставленных лапах и одна в изголовье. Изображение по периметру окантовано двумя рядами треугольников - рисунок, идентичный орнаменту, обрамляющему внутреннее кольцо филипповского медальона. По восстановленной цветовой гамме персепольского изображения [Curtus, Tallis, 2005, p. 95, cat. 77] идентично и распределение цветов. Внешний ряд - двуцветный с чередующимися по цвету треугольниками, один из которых красный, внутренний - одноцветный, бирюзового цвета. Согласно легенде, отраженной в Авесте, птица из семейства соколиных по имени Veraghna являлась, с одной стороны, хранительницей святыни, с другой - только она могла как приносить сияние «khvarenah», так и забрать его. Таким образом, Veraghna в авестийской интерпретации сама олицетворяет божественное сияние «khvarenah», а двухрядный орнамент треугольников символизирует лучи / сияние святыни [Soudavar, 2005, p. 123124; 2018, p. 27, fig. 29,a].

Подводя итог проведенному исследованию, надо сказать, что анализ контекста представленного ювелирного изделия в погребении и выявленных особенностей его технологии изготовления и конструкции убедительно показал: предмет не носился как украшение в повседневной / светской жизни, а служил драгоценной реликвией, которая могла использоваться только кратковременно в религиозных церемониях и ритуальных практиках. Остальное время она бережно хранилась аккуратно сложенной среди других сакральных предметов в коробе. Конструкция предмета - круглый диск, обрамленный радиально расходящимися вертикальными подвесками, представляет символику древнеиранского солярного культа, а сам предмет олицетворял солнце. Наиболее близкие к диску подвески в форме месяца, вероятно, относятся к лунной символике. Примечательно, что они надеты только поверх 20 цепочек из 27 и отсутствуют поверх 7 коротких цепочек в верхнем секторе диска. Более того, эти 7 цепочек прикреплены к дис- 
ку оборотной стороной украшающих их подвесок. И они «играют», только если цепочки перекинуты на лицевую сторону медальона, закрывая изображение крылатого солнечного диска. Не исключено, что в расположении цепочек заложен цифровой код, связанный с символикой лунного месяца (27 цепочек + диск $=28)$ и времени / периодичности проведения ритуалов (20 цепочек с лунной символикой и 7 цепочек без них).

Поиски аналогий образам на центральном медальоне позволили уточнить их семантику и предложить смысловую нагрузку составленной композиции. В центре изображено «древо жизни», помещенное в замкнутое пространство: его ствол и боковые ветви защищены фигурами, клювами и крыльями двух стоящих птиц, корни прикрыты их мощными когтистыми лапами, сверху отведенные в стороны головы птиц смыкаются с окончаниями распростертых крыльев крылатого диска. Иконография крылатого диска характерна для абстрактного древнеиранского божества Хварна (khvarenah / khvarnah), дарующего сияние благодати и фортуну стоящему под ним. Отмеченные черты иконографии птиц характерны для священной птицы Veraghna, которая являлась, с одной стороны, хранительницей божественного сияния Хварна, с другой могла переносить божество. Определенная композиция персонажей в филипповском медальоне показывает, что ее центральным персонажем является священное дерево, охраняемое божественной силой Хварны, представленного в двух ипостасях - крылатого диска и священных птиц Veraghna. Мы можем определить общий смысл ритуалов, в которых участвует священное дерево, отражающих идею приумножения плодородия во всех его проявлениях: обеспечении благополучия и приумножении потомства, здоровья, богатства и преуспевании рода.

Использованная в медальоне композиционная схема - новоассирийская - появилась в начале IX в. до н.э. и активно тиражировалась начиная с VIII-VII вв. до н.э. в Урарту и, вероятно, в доахеменидской Мидии. Находка этой уникальной реликвии в раннекочевническом погребении, датирующемся в пределах IV в. до н.э., свидетельствует не только о широкой преемственнос- ти религиозных постулатов, продолжающих существовать в сатрапиях ахеменидского Ирана, но и о распространении их в кочевнической среде и восприятии элитой сарматских племен Южного Приуралья.

Наиболее близкие аналогии изученной подвеске найдены также в филипповском могильнике. Все предметы имеют аналогичную конструкцию основания и радиально расположенных подвесок-цепочек. Первые две подвески (из кургана 1 погребение 2, из кургана 17 погребение 1) являются практически полными аналогами. Инкрустация медальона последней - восьмилучевая звезда с кругом в центре - подчеркивает солярную символику конструкции обеих подвесок. При этом фигурные привески на лучах-цепочках, вероятно, изображают разнообразные плоды, отражая изобилие и благоденствие. Изображения шестилучевых звезд с окружностью в центре, выполненные в технике перегородчатой инкрустации, и восьмилучевых звезд распространены в уздечных бляхах из памятников Закавказья, датированных VIII-VII вв. до н.э. [Рябкова, 2014, с. 165, рис. 1,1-5,9].

Назначение и семантику третьей подвески (межкурганное пространство кургана 1) определить сложнее. Композиционным центром подвески является объемная фигурка стоящего кабана, но цепочки с фигурными привесками, также изображающие разнообразные плоды, заканчиваются концевыми овальными привесками с двусторонним изображением голов фантастических зверей.

Образы кабанов редко встречаются в зверином стиле Южного Урала и представлены исключительно материалами Филипповки 1 [Переводчикова, Таиров, 2009, с. 93]. В мотивах преобладает стоящая в полный рост фигура животного с опущенной головой: 4 однотипные накладки на деревянные сосуды [Пшеничнюк, 2012, с. 78, рис. 14,4], 3 одинаковые оковки деревянных чаш [Пшеничнюк, 2012, c. 83, рис. 14,3], фигуры на литом перекрестии меча и инкрустации по клинку меча [Яблонский, 2013, с. 86-87, кат. 296], объемные фигурки на дроте гривны [Яблонский, 2013, c. 221, кат. 3118]. Изображения головы вепря единичны: подвеска-цепочка, заканчивающаяся литой головой животного [Пшеничнюк, 2012 , с. 74 , рис. 45 ]; колчанный крюк с голо- 
вами ушастого грифона и кабана [Яблонский, 2013 , с. 80 , кат. 114].

В середине - второй половине I тыс. до н.э. разнообразная иконография образа представлена в петроглифах и оленных камнях Центральной Азии, Южной Сибири, Восточного Казахстана, в прикладном искусстве раннесакских комплексов, тагарской и пазырыкской культур [Черемисин, 2008, с. 28-33; Самашев, 1992, с. 160 , рис. 173; Членова, 1967, с. 273, табл. 23]. Характерные черты иконографии (острые зубы и язык в раскрытой пасти, изображения когтей наряду с копытами на ногах), очевидно, определялись представлениями о кабане, бытовавшими в среде ранних кочевников: являясь копытным животным, кабан был очень опасен для человека и поэтому ассоциировался с хищными животными.

В изобразительной системе звериного стиля существовал ряд признаков, общих для кабанов и хищников, отличный от изображений других копытных. Таким образом, место кабана определялось как промежуточное между хищными и копытными, скорее приближаясь к плотоядным. Являясь копытным, кабан был опаснее многих хищников, что отражено в иконографии образа, где кабан противопоставляется кошачьим хищникам как равноценный противник, а не объект терзания. Его изображения использовались для декоративной отделки оружия, конской упряжи и служили оберегами / амулетами (как и подвески из кабаньих клыков) для людей и коней [Смирнов, 1964, с. 29]. Характерной особенностью иконографии образа в восточных районах (Южная Сибирь, Южное Приуралье, Нижнее Поволжье) является полная стоящая фигурка кабана. В западных областях (Европейская Скифия, Сарды, Эфес, Луристан, Малая Азия) вепри чаще изображались с подогнутыми ногами, в позе припавшего к земле хищного животного [Переводчикова, 1994, с. 46-48; Королькова, 2006, с. 45-46, 178, табл. 9-10].

Для всей степной Евразии образ кабана у древних индоиранцев являлся сакральным символом, олицетворяя прародителя, идею плодородия и воинственности, он объединялся с образами хищников и ассоциировался с войной, охотой, смертью и потусторонним ми- ром [Королькова, 2006, с. 114-117; Черемисин, 2008, с. 30-31]. Существует мнение, что кабан являлся проводником между средним и нижним мирами в третичной мифологической модели космоса у кочевников [Переводчикова, 1994, с. 46-48; Королькова, 2006, c. 117-119]. Согласно Авесте, кабан (вепрь) являлся пятым и наиболее распространенным воплощением божества войны и победы Веретрагны [Вертиенко, 2014, с. 272], бесстрашным зверем, разящим и терзающим врагов [Черемисин, 2008, с. 33]. В древнеиранской мифологии в образе кабана акцентирована семантическая линия кабан-геройвоин для обозначения различных видов геройства, отваги и доблести [Вертиенко, 2014, c. 275]. Кроме того, вепрь был косвенно связан с понятием Хварна и подчеркивал высокий социальный статус владельца в воинской иерархии, носители таких изображений воспринимались как обладатели Хварна счастья - счастливой судьбы [Вертиенко, 2014, c. 276-278].

Строение филипповской подвески подразумевает, что она подвешивалась за верхнюю петлю. Центром ее композиции, безусловно, является фигура кабана, лоб которого украшен ромбическим кастом, окантованным зернью. Этот символ встречен в оформлении фигуры животного впервые, в отличие от аналогично оформленных кастов в форме «запятой» на бедрах, которые часты в декорации фигур разных животных в предметах ахеменидского круга на Южном Урале. Практически половину объема фигуры занимает массивная голова с рельефным изображением клыков и ушей. В ее облике акцентированы не агрессивные черты, а героические (мощь, доблесть, сила). На наш взгляд, иконография подвески обусловливает смысловую нагрузку образа кабана - как воина-хранителя изобилия, плодородия, благоденствия (цепочки с подвесками, изображающими различные плоды), что подчеркивается наличием привесок с изображением морд фантастических животных на концах цепочек. Учитывая косвенную связь кабана с понятием Хварна, нельзя исключить и сакральную символику божественной силы, обеспечивающей фортуну, процветание и счастье носителю / хранителю этой реликвии. 
О.В. Аникеева, Г.Ю. Колганова. Ювелирное изделие из погребения 2 кургана 1 могильника Филипповка 1

\section{ПРИМЕЧАНИЯ}

1 Авторы выражают глубокую благодарность реставратору высшей категории М.В. Нацкому (ГОСНИИР, г. Москва), который исследовал технологию изготовления и под руководством которого написан этот раздел.

2 Термин «фритта» (итал. fritta, англ. frit) здесь и далее используется для обозначения богатой кремнеземом стекловидной пасты, обожженной на малом огне до спекания (но не сплавления) массы. Это обусловливает совершенно иной, отличный от классического стекла рисунок поверхности под бинокуляром. Для него характерны неоднородная разнозернистая текстура, присутствие пор и вкраплен- ных в стекловидные гранулы органических частиц и почвенных микроагрегатов.

${ }^{3}$ Мы подробно рассмотрели систему взаиморасположения цепочек и количество звеньев в них, поскольку специалисты по семантике образов основной композиции медальона считают, что в логике расположения может содержаться цифровой код Авесты, расшифровка которого даст дополнительную информацию о смысле / содержании культовых действий, в которых изделие использовалось.

4 Данное мнение М.В. Нацким было сформулировано в процессе исследования технологии изготовления подвески и высказано в ходе личной беседы с авторами статьи. 
O.V. Anikeeva, G.Yu. Kolganova. Jewellery from Burial 2 Kurgan 1 Filippovka 1 Cemetery

\section{ИЛЛЮСТРАЦИИ}

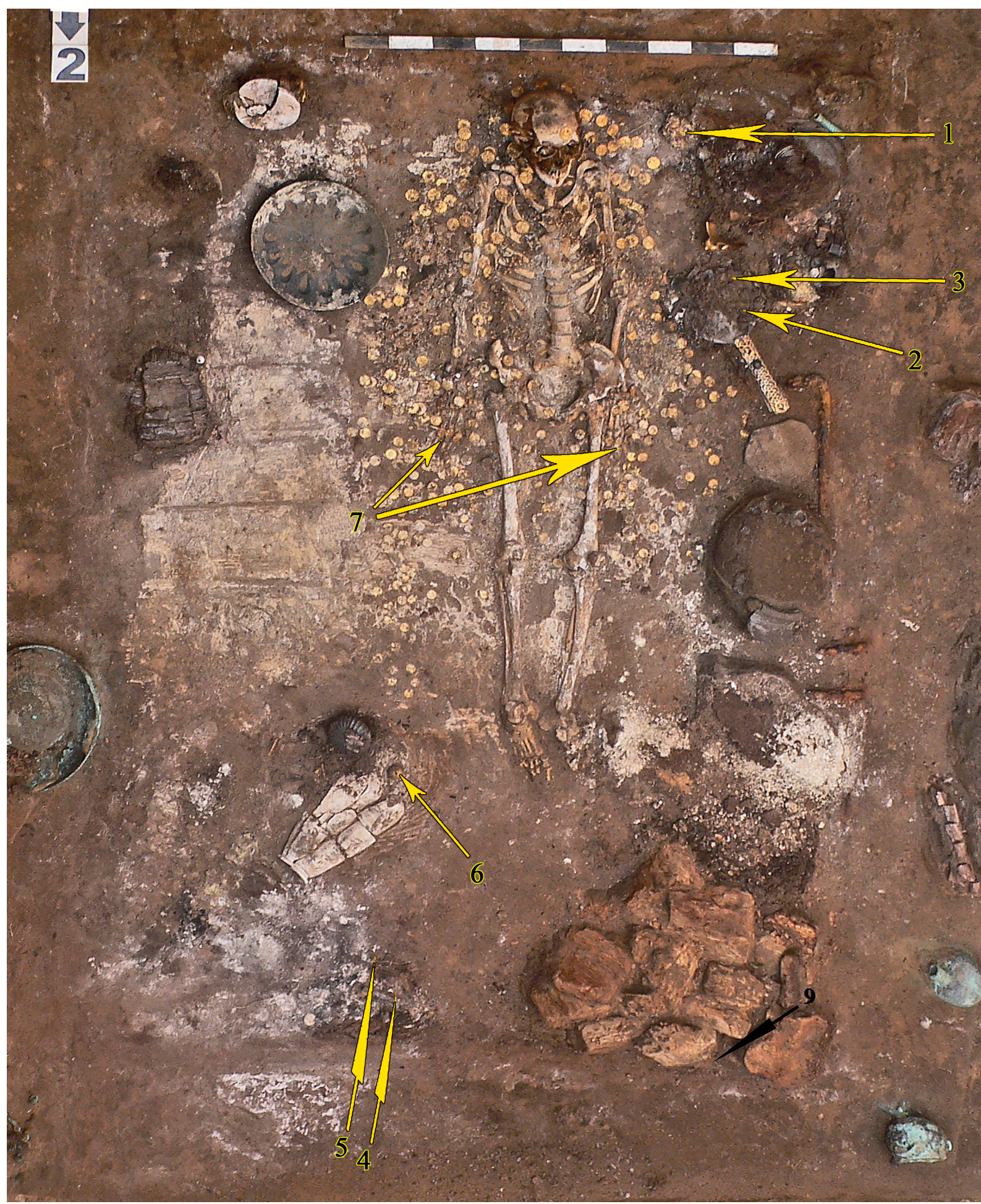

Рис. 1. Могильник Филипповка 1, курган 1, погребение 2 (фото О.В. Аникеевой):

План: 1 - дисковидное изделие; 2 - зеркало; 3 - амулет Глаз Хора; 4 - палитры; 5 - фрагменты кожаного пояса; 6 - сферическая пронизь; 7 - каменные печати

Fig. 1. Filippovka 1 cemetery. Kurgan 1, Burial 2 (Photograph by O.V. Anikeeva):

Plan: 1 - disk-shaped jewellery; 2 - mirror; 3 - amulet "The Eye of Horus"; 4 - palettes; 5 - leather belt; 6 - spherical bead; 7 - stone stamp seals 


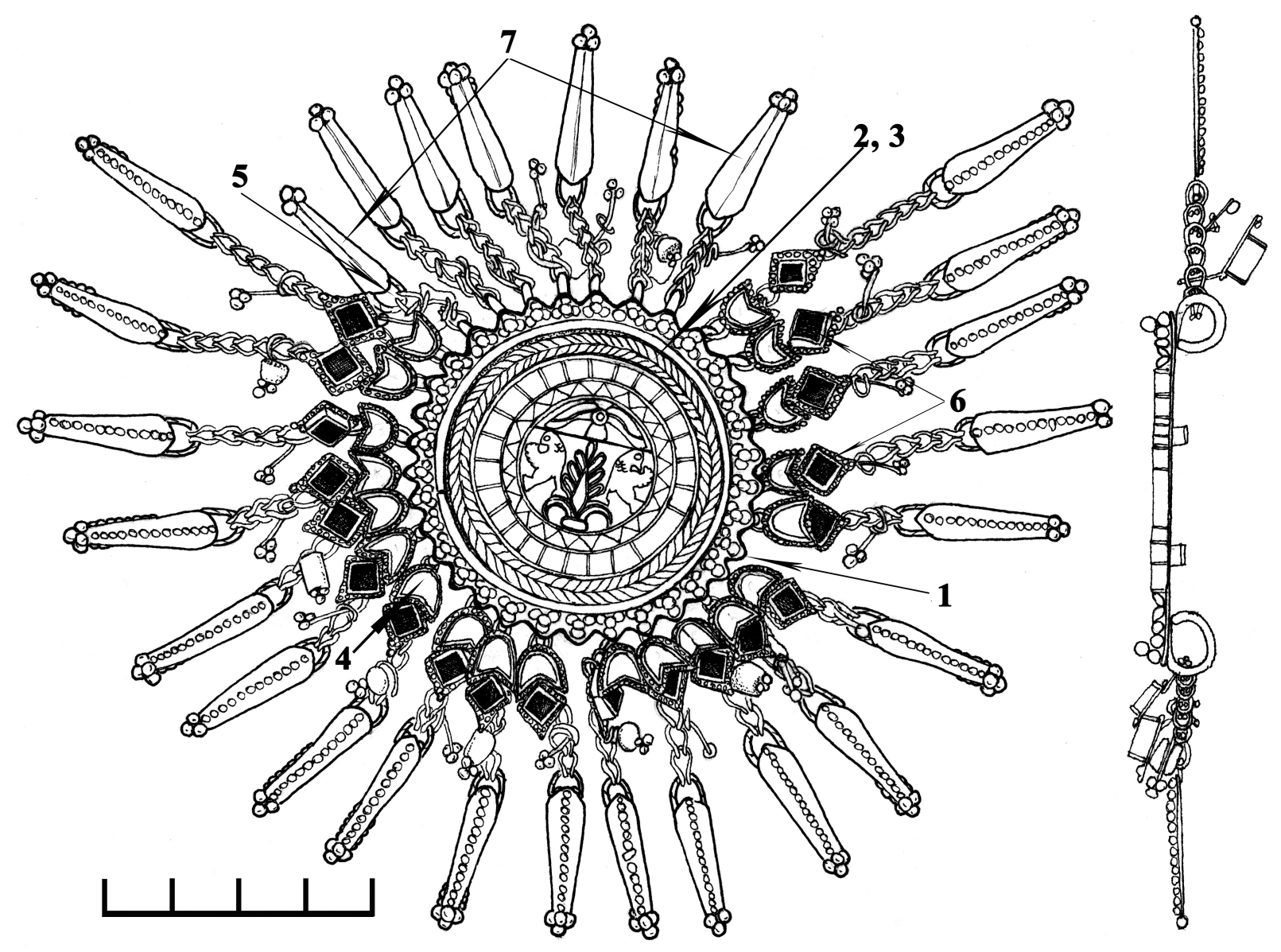

Рис. 2. Могильник Филипповка 1 курган 1, погребение 2. Ювелирное изделие - подвеска, лицевая сторона (рис. К.С. Окорокова):

1-7 - элементы конструкции изделия (см. разделы статьи «Изучение технологии изготовления», «Конструкция и способы крепления изделия»). ОГИКМ КП 20283/4

Fig. 2. Filippovka 1 cemetery. Kurgan 1, Burial 2. Pendant, front side (Drawing by K.S. Okorokov): 1-7 - design elements (see the sections of the paper "Study of manufacturing technology", "Design and mounting methods"). ОГИКМ КП 20283/4 


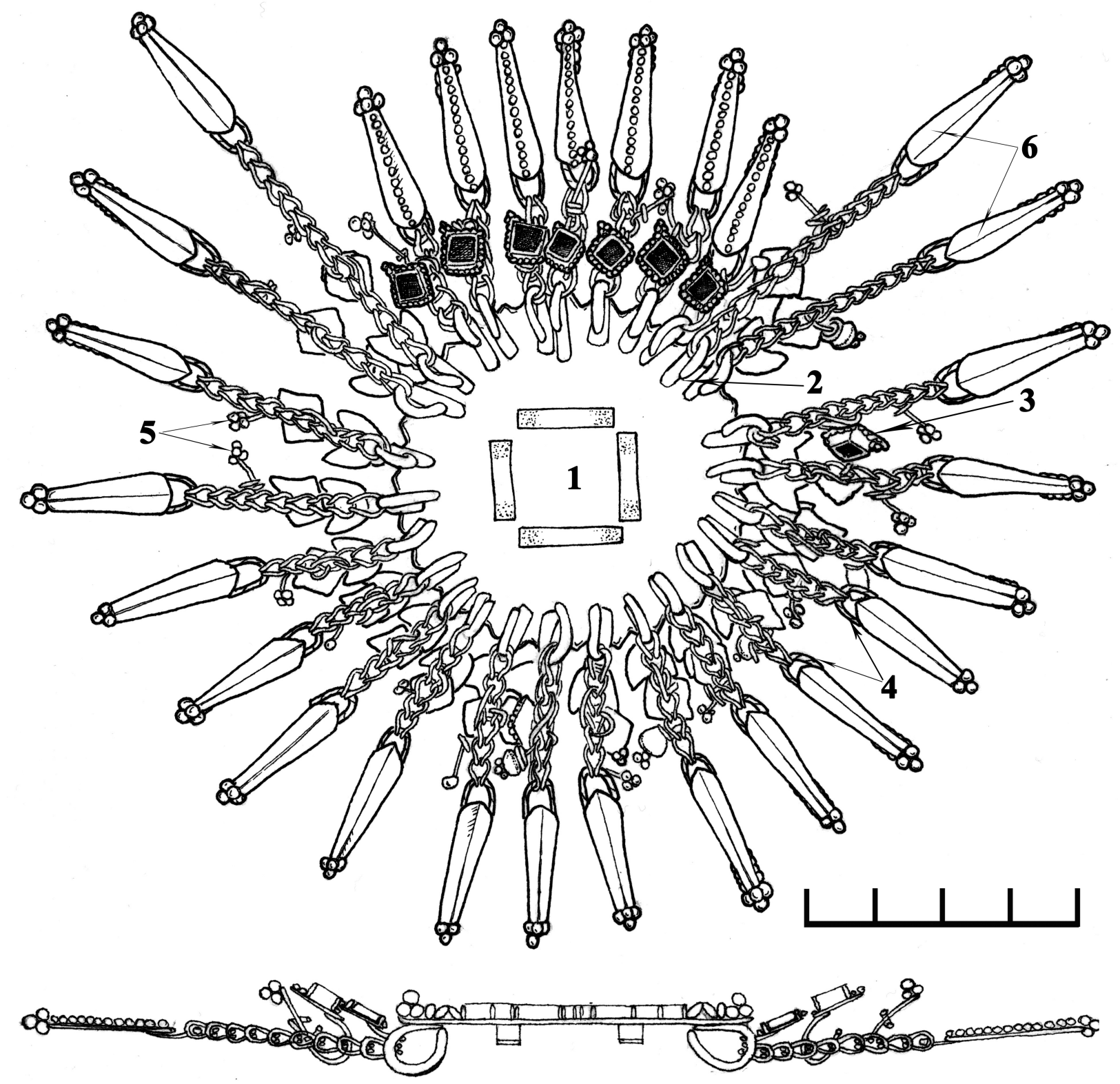

Рис. 3. Могильник Филипповка 1, курган 1, погребение 2.

Ювелирное изделие - подвеска, оборотная сторона (рис. К.С. Окорокова):

1-6 - элементы конструкции изделия (см. разделы статьи «Изучение технологии изготовления», «Конструкция и способы крепления изделия»). ОГИКМ КП 20283/4

Fig. 3. Filippovka 1 cemetery. Kurgan 1, Burial 2. Pendant, flip side (Drawing by K.S. Okorokov):

1-6 - design elements (see the sections of the paper "Study of manufacturing technology",

"Design and mounting methods"). ОГИМК КП 20283/4 
О.В. Аникеева, Г.Ю. Колганова. Ювелирное изделие из погребения 2 кургана 1 могильника Филипповка 1

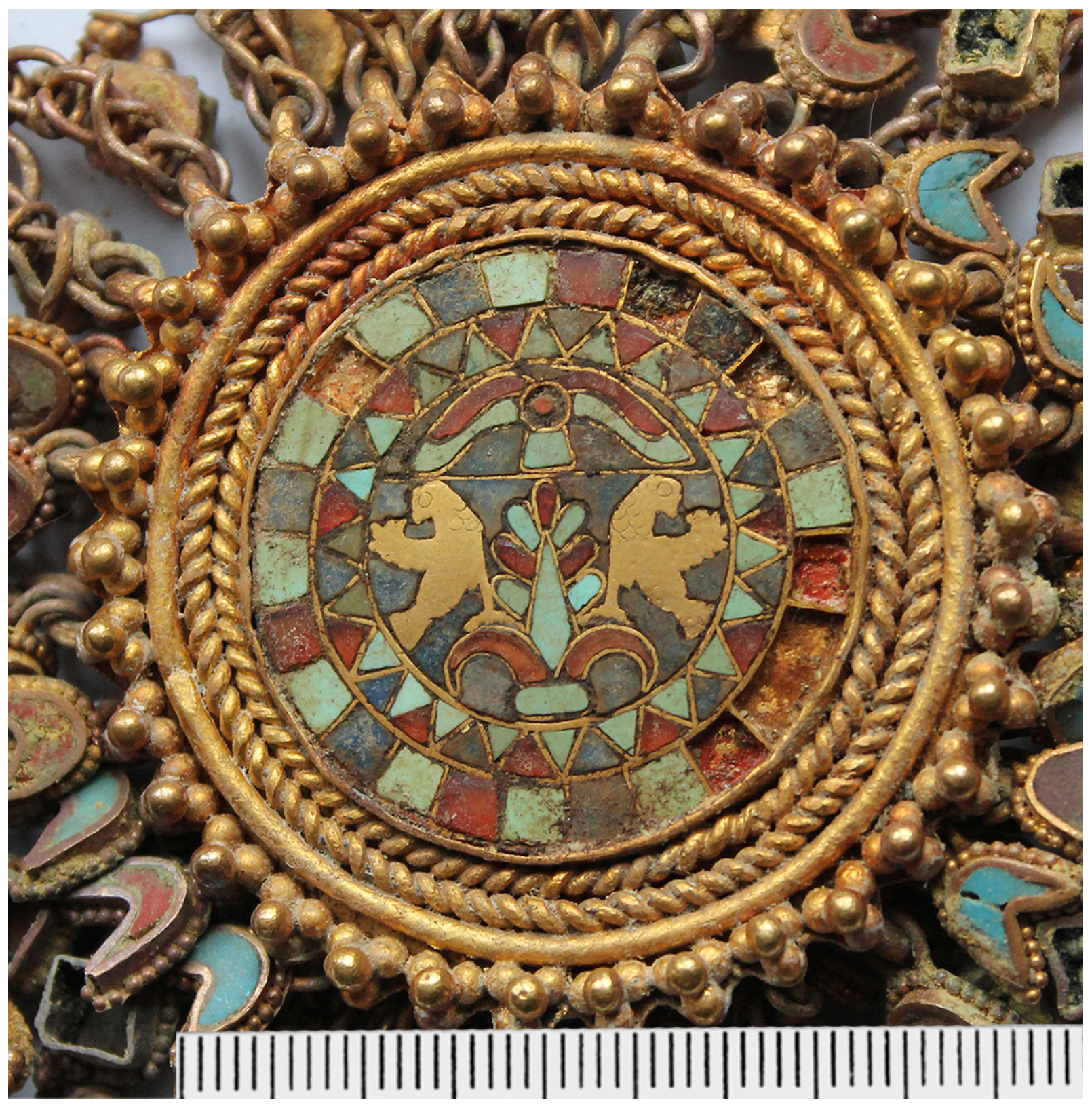

Рис. 4. Центральный медальон ювелирного изделия. Фото О.В. Аникеевой

Fig. 4. Central medallion of jewellery. Photo by O.V. Anikeeva 


\section{СПИСОК ЛИТЕРАТУРЫ}

Аникеева О. В., Яблонский Л. Т., 2018. Амулеты «Глаз Хора» из курганов ранних кочевников на Южном Урале // Вестник Волгоградского государственного университета. Серия 4. История. Регионоведение. Международные отношения. Т. 23, № 3. С. 63-81. DOI: https://doi.org/10.15688/jvolsu4.2018.3.6.

Аникеева О. В., Яблонский Л. Т., 2019а. Элементы погребального костюма жрицы из филипповских курганов: материалы к реконструкции // Археология евразийских степей. № 1. С. 12-32.

Аникеева О. В., Яблонский Л. Т., 2019б. Техника изготовления ювелирных украшений из погребения 2 кургана 1 могильника Филипповка 1 и вероятные центры изготовления // Уфимский археологический вестник. Вып. 19. С. 25-38.

Аникеева О. В., Нацкий М. В., Шемаханская М. С., Яблонский Л. Т., 2018. Ювелирные украшения из погребения знатной женщины (могильник Филипповка 1, курган 1, погребение 2) // Духовная модернизация и археологическое наследие : материалы Междунар. науч.-практ. конф. «Маргулановские чтения - 2018». Алматы ; Актобе : Институг археологии им. А.Х. Маргулана. С. 211-219.

Вертиенко А. В., 2014. Образ вепря в иранской традиции - нарратив и визуализация // Stratum plus. № 3. C. $271-280$.

Королькова Е. Ф., 2006. Звериный стиль Евразии. Искусство племен Нижнего Поволжья и Южного Приуралья в скифскую эпоху (VII-IV вв. до н.э.). Проблемы стиля и этнокультурной принадлежности. СПб. : Петербургское востоковедение. $272 \mathrm{c}$.

Переводчикова Е. М., 1994. Язык звериных образов. Очерки искусства евразийских степей скифской эпохи. М. : Восточная литература. $204 \mathrm{c}$.

Переводчикова Е. М., Таиров А. Д., 2009. Звериный стиль Филипповского кургана 1 в контексте искусства кочевников Южного Урала // Этнические взаимодействия на Южном Урале : материалы IV регион. (с междунар. участием) науч.-практ. конф. Челябинск : Изд-во ЮУрГУ. С. 92-94.

Пиотровский Б. Б., 1959. Ванское царство (Урарту). М. : Восточная литература. 283 с.

Пиотровский Б. Б., 1970. Кармир-блур ІІ. Результаты раскопок 1949-1950. Л. : Аврора. 129 с.

Пшеничнюк А. Х., 2012. Филипповка. Некрополь кочевой знати IV в. до н.э. на Южном Урале. Уфа : ИИЯЛ УНЦРАН. $277 \mathrm{c}$.

Рябкова Т. В., 2014. Изделия с перегородчатой инкрустацией в предскифских и раннескифских памятниках // Труды IV (XX) Всероссийского археологического съезда. Т. II. Казань : Отечество. С. 163-168.

Самашев 3. С., 1992. Наскальные изображения Верхнего Прииртышья. Алма-Ата : Гылым. 288 с.

Смирнов К. Ф., 1964. Савроматы. Ранняя история и культура сарматов. М. : Наука. 377 с.

Трейстер М. Ю., Яблонский Л. Т., 2012. Влияния ахеменидской культуры в Южном Приуралье (V-III вв. дон.э.) : в 2 т. М. : ТАУC. Т. I- 671 с.; T. II -468 c.

Черемисин Д. В., 2008. Искусство звериного стиля в погребальных комплексах рядового населения пазырыкской культуры. Семантика звериных образов в контексте погребального обряда. Новосибирск : ИАЭ СО РАН. $136 \mathrm{c}$.

Членова Н. Л., 1967. Происхождение и ранняя история племен тагарской культуры. М. : Наука. 300 с.

Яблонский Л. Т., 2013. Золото сарматских вождей. Элитный некрополь Филипповка 1 (по материалам раскопок 2004-2009 гг.). Каталог коллекции. Кн. 1. М. : ИА РАН. 231 с.

Яблонский Л. Т., 2014. Новые находки в «царском» кургане 1 могильника Филипповка 1 (предварительное сообщение) // Краткие сообщения института археологии. Вып. 232. С. 3-7.

Яблонский Л. Т., 2015. Новые необыкновенные находки из кургана могильника Филипповка 1 // Археология, этнография и антропология Евразии. Т. 43, № 2. С. 97-108.

Яблонский Л. Т., 2016а. Новые археологические данные об ахеменидских влияниях на Южном Урале // Вестник древней истории. Т. 76, № 3. С. 744-766.

Яблонский Л. Т., 2016б. Об одном аспекте социальной роли женщины в раннекочевом сообществе Южного Приуралья (по материалам могильника Филипповка 1) // Кадырбаевские чтения-2016 : материалы V Междунар. науч. конф. Актобе : Институт археологии им. А.Х. Маргулана. С. 15-19.

Batmaz A., 2013. A New Ceremonial Practice at Ayanis Fortress: The Urartian Sacred Tree Ritual on the Eastern Shore of Lake Van // Journal of Near Eastern Studies. Vol. 72, № 1. P. 65-83. 
Curtus J., Tallis N., 2005. Forgotten Empires. The World of Ancient Persia. London : The British Museum press. $272 \mathrm{p}$.

Giovino M., 2007. The Assyrian Sacred Tree: A History of Interpretation. Fribourg : Academic Press. 243 p.

Higgins R., 1979. The Aegina Treasure. An Archaeological Mystery. London : British Museum Publications. 72 p.

Kia M., 2016. The Persian Empire: A Historical Encyclopedia. Empires of the World. Vol. I. Santa-Barbara : ABC-CLIO. 397 p.

Michaux-Colombot D., 2008. The Royal Hittite Title 'My Sun' and the Winged Sun Disk // 38. ICANAS. Religion. Vol. 1. International Congress of Asian and North African Studies. Ankara. P. 329-353.

Maxwell-Hislop K.R., 1974. Western Asiatic Jewellery c. 3000-612 B.C. London : Methen\&Co Ltd. 275 p.

Porada E. 1965. The Art of Ancient Iran. New York : Crown Publishers. 279 p.

Soudavar A., 2005. The Formation of Achaemenid Imperial Ideology and Its Impact on Avesta // The World of Achaemenid Persia. London; New York : I.B. Taurisp. P. 111-138.

Soudavar A., 2018. Iranian Complexities: A Study in Achaemenid, Avestian, and Sasanian Controversies. Houston. $234 \mathrm{p}$.

Yablonsky L.T., Treister M.Yu., 2019. New Archaeological Data on Achaemenid Influences in the Southern Urals // Ancient Civilizations from Scythia to Siberia. Vol. 25. P. 79-161

\section{REFERENCES}

Anikeeva O.V., Yablonsky L.T., 2018. Amulety «Glaz Hora» iz kurganov rannih kochevnikov na Yuzhnom Urale [Amulets Depicting the Eye of Horus from Burial Mounds of Early Nomads in the Southern Urals]. Vestnik Volgogradskogo gosudarstvennogo universiteta. Seriya 4. Istoriya. Regionovedenie. Mezhdunarodnye otnosheniya [Science Journal of Volgograd State University. History. Area Studies. International Relations], vol. 23, no. 3, pp. 63-81. DOI: https://doi.org/10.15688/jvolsu4.2018.3.6.

Anikeeva O.V., Yablonsky L.T., 2019a. Elementy pogrebal'nogo kostyuma zhricy iz filippovskih kurganov: materialy k rekonstrukcyi [Elements of Priestess Funeral Dress from Filippovka I Buriel Ground: Materials to Reconstruction]. Arheologiya evraziiyskih stepey [Archaeology of the Eurasian Steppe], no. 1, pp. 12-32.

Anikeeva O.V., Yablonskiy L.T., 2019b. Tehnika izgotovleniya yuvelirnyh ukrasheniy iz pogrebeniya 2 kurgana 1 mogil'nika Filippovka 1 i veroyatnye centry izgotovlenya [Technique of Manufacturing Jewelery from the Burial 2 Barrow 1 from Philippovka-1 and Probable Centers of Manufacturing]. Ufimskiy arheologicheskiy vestnik [Ufa Archaeological Herald], vol. 19, pp. 25-38.

Anikeeva O.V., Natskiy M.V., Shemahanskaya M.S., Yablonskiy L.T., 2018. Yuvelirnye ukrasheniya iz pogrebeniya znatnoy zhenshchiny (mogil'nik Filippovka 1, kurgan 1, pogrebenie 2) [Jewelry from the Burial of a Noble Woman (Filippovka 1 kurgan cemetery, Kurgan 1 Burial 2)]. Duhovnaya modernizatsiya i arheologicheskoe nasledie: materialy Mezhdunar. nauch.-prakt. konf. «Margulanovskie chteniya - 2018» [Proceedings of the International Scientific-Practical Conference "Margulanov Readings - 2018"]. Almaty; Aktobe, Institute of Archaeology named after A. Kh. Margulan, pp. 211-219.

Vertienko A.V., 2014. Obraz veprya v iranskoy tradicii - narrativ i vizualizaciya [The Image of the Boar in the Iranian Tradition - Narrative and Visualization]. Stratum plus, no. 3, pp. 271-280.

Korol'kova E.F., 2006. Zveriniy stil' Evrazii. Iskusstvo plemen Nizhnego Povolzh'ya i Yuzhnogo Priural'ya v skifskuyu epohu (VII-IVvv. do n.je.). Problemy stilya i etnokul turnoj prinadlezhnosti [The Animal Style of Eurasia. Art of the Lower Volga and South Urals Tribes in Scythian Epoch (VII-IV centuries BX). Problems of Style and Ethnocultural Affiliation]. Saint Petersburg, Peterburgskoe vostokovedenie Publ. 272 p.

Perevodchikova E.M., 1994. Yazyk zverinyh obrazov. Ocherki iskusstva evraziyskih stepey skifskoy epohi [The Language of Animal Images. Essays on the Art of the Eurasian Steppes of the Scythian Epoch]. Moscow, Vostochnaya literature Publ. 204 p.

Perevodchikova E.M., Tairov A.D., 2009. Zverinyy stil' Filippovskogo kurgana 1 v kontekste iskusstva kochevnikov Yuzhnogo Urala [The Animal Style of the Filippovka Kurgan 1 in the Context of Nomad Art in the Southern Urals]. Yetnicheskie vzaimodeystviya na Yuzhnom Urale: materialy IV region. (s mezhdunar. uchastiem) nauch.-prakt. konf. [Ethnic Interactions in the Southern Urals. Proceedings of the $4^{\text {th }}$ Regional (with International Participation) Scientific Conference]. Chelyabinsk, Southern Urals State University, pp. 92-94. 
Piotrovskiy B.B., 1959. Vanskoe Tsarstvo (Urartu) [The Kingdom of Van (Urartu)]. Moscow, Vostochnaya literature Publ. 283 p.

Piotrovskiy B.B., 1970. Karmir-blur II. Rezul taty raskopok 1949-1950. [Karmir-blur II. The Results of Excavations]. Leningrad, Avrora Publ. 129 p.

Pshenichnyuk A.H., 2012. Filippovka. Nekropol'kochevoy znati IVv. do n.e. na Yuzhnom Urale [Filippovka. The Necropolis of Nomadic Nobility in the Southern Urals (IV century BC)]. Ufa, IHLL USC RAS. 277 p.

Ryabkova T.V., 2014. Izdeliya s peregorodchatoy inkrustaciey v predskifskih i ranneskifskih pamyatnikah [Items with Cloisonne Inlay in the Prescythian and Early Scythian Monuments]. Trudy IV(XX) Vserossiyskogo arheologicheskogo s'ezda [Proceedings of the $4^{\text {th }}\left(20^{\text {th }}\right)$ All-Russian Archaeological Congress], vol. II. Kazan', Otechestvo Publ., pp. 163-168.

Samashev Z.S., 1992. Naskal'nye izobrazheniya Verhnego Priirtysh'ya [The Rock Paintings of the Upper Irtysh]. Alma-Ata, Gylym Publ. 288 p.

Smirnov K.F., 1964. Savromaty. Rannjaja istorija i kul tura sarmatov [Sauromats. TheEearly Sarmatians History and Culture]. Moscow, Nauka Publ. 377 p.

Treister M.Yu., Yablonsky L.T., 2012. Vliyaniya akhemenidskoy cul 'tury v Yuzhnom Priural'e (V-III vv. do n.e.): $v 2 t$. [Influences of the Achaemenid Culture in the Southern Urals (V-III centuries BC). In 2 vols.]. Moscow, TAUS Publ. Vol. I. 671 p.; vol. II. 468 p.

Cheremisin D.V., 2008. Iskusstvo zverinogo stilya v pogrebal'nyh kompleksah ryadovogo naseleniya pazyrykskoy kul'tury. Semantika zverinyh obrazov v kontekste pogrebal'nogo obryada [Animal Style art in the Burial Complexes of the Ordinary Population of the Pazyryk Culture. The Semantics of Animal Images in the Context of a Funeral Rite]. Novosibirsk, IAE SB RAS. 136 p.

Chlenova N.L., 1967. Proishozhdenie i rannyaya istoriya plemyon tagarskoy kul'tury [The Origin and Early History of the Tagar Culture Tribes]. Moscow, Nauka Publ. 300 p.

Yablonskiy L.T., 2013. Zoloto sarmatskih vozhdey. Yelitniy nekropol' Filippovka 1 (po materialam raskopok 2004-2009 gg.). Katalog kollekcii [Gold of the Sarmatian Leaders. The Elite Necropolis Filippovka 1 (based on the 2004-2009 excavations)]. Book 1. Moscow, IA RAS. 231 p.

Yablonskiy L.T., 2014. Novye nahodki v «tsarskom» kurgane 1 mogil'nika Filippovka 1 (predvaritel'noe soobshchenie) [New Finds in the "Royal" Burial-Mound 1 in the Filippovka 1Cemetery (Preliminary Report)]. Kratkie soobshcheniya Instituta Arheologii [Brief Communications of the Institute of Archaeology], iss. 232, pp. 3-7.

Yablonsky L.T., 2015. Novye neobyknovennye nahodki iz kurgana mogil'nika Filippovka 1 [Unusual New Findings at Filippovka-1 Burial Mound 1, Southern Urals]. Arheologiya, etnografiya $i$ antropologiya Evrazii [Archaeology, Ethnology \& Anthropology of Eurasia], vol. 43, no. 2, pp. 97-108.

Yablonsky L.T., 2016a. Novye arheologicheskie dannye ob ahemenidskih vliyaniyah na Yuzhnom Urale [New Archaeological Data on the Achaemenid Influence in the Southern Ural Area]. Vestnik drevney istorii [Journal of Ancient History], vol. 76, no. 3, pp. 744-766.

Yablonsky L.T., 2016b. Ob odnom aspekte social'noy roli zhenshchiny v rannekochevom soobshchestve Yuzhnogo Priural'ya (po materialam mogil'nika Filippovka 1) [About One Aspect of the Social Role of Women in the Early Nomadic Community of the South Urals (Based on the Materials of the Philippovka 1 Kurgan Cemetery)]. Kadyrbaevskie chteniya-2016: materialy V Mezhdunar. nauch. conf. [Kadyrbaevskie Readigs-2016. Proceedings of the $5^{\text {th }}$ International Conference]. Aktobe, Institute of Archaeology named after A.Kh. Margulan, pp. 15-19.

Batmaz A., 2013. A New Ceremonial Practice at Ayanis Fortress: The Urartian Sacred Tree Ritual on the Eastern Shore of Lake Van. Journal of Near Eastern Studies, vol. 72, no. 1, pp. 65-83.

Curtus J., Tallis N., 2005. Forgotten Empires. The World of Ancient Persia. London, The British Museum press. $272 \mathrm{p}$.

Giovino M., 2007. The Assyrian Sacred Tree: A History of Interpretation. Fribourg, Academic Press. 243 p.

Higgins R., 1979. The Aegina Treasure. An Archaeological Mystery. London, British Museum Publications. 72 p.

Kia M., 2016. The Persian Empire: A Historical Encyclopedia. Empires of the World. Vol. I. Santa-Barbara, ABC-CLIO. 397 p.

Michaux-Colombot D., 2008. The Royal Hittite Title 'My Sun' and the Winged Sun Disk. 38. ICANAS. Religion. Vol. 1. International Congress of Asian and North African Studies. Ankara, pp. 329-353. 
О.В. Аникеева, Г.Ю. Колганова. Ювелирное изделие из погребения 2 кургана 1 могильника Филипповка 1

Maxwell-Hislop K.R., 1974. Western Asiatic Jewellery c. 3000-612 BC. London, Methen\&Co Ltd. 275 p.

Porada E. 1965. The Art of Ancient Iran. New York, Crown Publishers. 279 p.

Soudavar A., 2005. The Formation of Achaemenid Imperial Ideology and its Impact on Avesta. The World of Achaemenid Persia. London, New York, I.B. Taurisp, pp. 111-138.

Soudavar A., 2018. Iranian Complexities: a Study in Achaemenid, Avestian, and Sasanian Controversies. Houston. $234 \mathrm{p}$.

Yablonsky L.T., Treister M.Yu., 2019. New Archaeological Data on Achaemenid Influences in the Southern Urals. Ancient Civilizations from Scythia to Siberia, vol. 25, pp. 79-161.

\section{Information About the Authors}

Olga V. Anikeeva, Candidate of Sciences (Geology \& Mineralogy), Leading Researcher, Department of Monumental Sculpture, State Research Institute for Restoration, Gastello St., 44/1, 107014 Moscow, Russian Federation, olganikeeva@yandex.ru, https://orcid.org/0000-0002-8725-4171

Galina Yu. Kolganova, Researcher, Department of History and Culture of the Ancient East, Institute of Oriental Studies of the Russian Academy of Sciences, Rozhdestvenskaya St., 12, 107031 Moscow, Russian Federation; Senior Researcher, Department of the Ancient East, State Museum of Fine Arts named after A.S. Pushkin, Volhonka St., 12, Moscow, Russian Federation, kolganova_gy@mail.ru, https://orcid.org/0000-0002-6886-728X

\section{Информация об авторах}

Ольга Викторовна Аникеева, кандидат геолого-минералогических наук, ведущий научный сотрудник отдела реставрации монументальной скульптуры, Государственный научно-исследовательский институт реставрации, ул. Гастелло, 44, стр. 1, 107014 г. Москва, Российская Федерация, olganikeeva@yandex.ru,https://orcid.org/0000-0002-8725-4171

Галина Юрьевна Колганова, научный сотрудник отдела истории и культуры Древнего Востока, Институт востоковедения РАН, ул. Рождественская, 12, 107031 г. Москва, Российская Федерация; старший научный сотрудник отдела Древнего Востока, Государственный музей изобразительных искусств им. А.С. Пушкина, ул. Волхонка, 12, г. Москва, Российская Федерация, kolganova_gy@mail.ru, https://orcid.org/0000-0002-6886-728X 